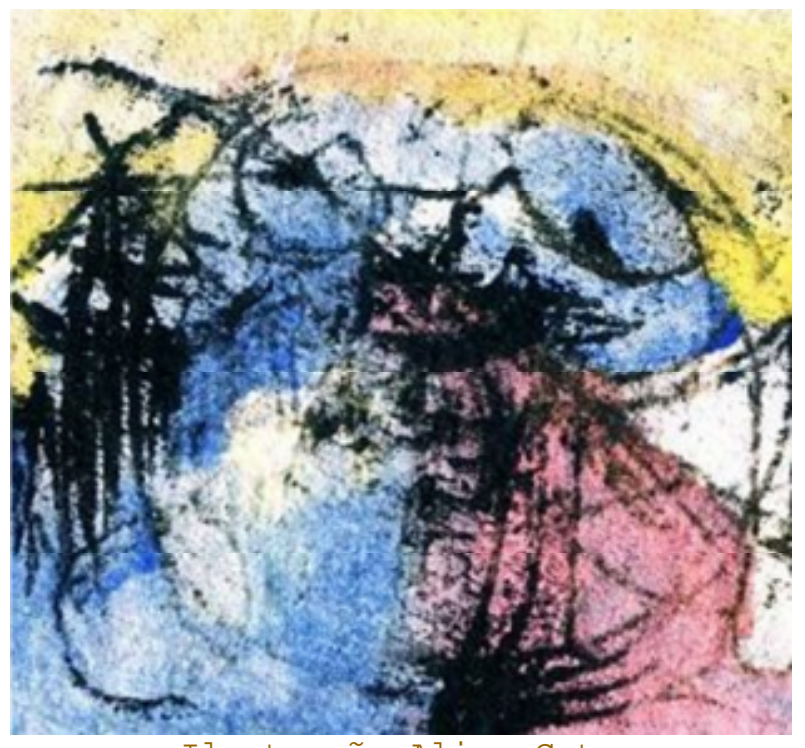

Ilustração Aline Cota

\title{
Histórias de mulheres e leituras
}

\section{Anna Nascimento da Silva}

Anna Nascimento da Silva tem 82 anos e nasceu no interior da Bahia, onde viveu até 1973, quando se mudou para osasco. Tendo enviuvado ainda jovem, ela tem uma filha, oito netos, seis bisnetos e uma tataraneta. Anna vai à missa toda semana, participa da Pastoral da saúde e gosta da novela das seis e do telejornal local.

Dona Anna, a senhora é analfabeta?

Eu escrevo meu nome, porque meu marido me ensinou.

Na época em que a senhora era criança, a escola ficava na zona rural?

A escola que eu conheci era na casa de meu pai. As pessoas da vizinhança se juntavam e pagavam um professor, que a gente chamava de "mestre": pagavam por mês e ele vinha ensinar a 
muitos meninos. Havia 10 alunos em cada turma e eles estudavam o dia todo. O professor morava longe, por isso precisava ficar por mais tempo na casa onde era contratado. Ali, ele comia, dormia e ensinava, ficando três meses em cada casa da região.

\section{Os alunos moravam perto da escola?}

Alguns moravam perto, outros tinham que andar 2, 3 léguas pra chegar. Não usavam cavalo, porque não precisava.

\section{Os alunos de cada turma tinham a mesma idade?}

Não, era tudo misturado: de 7 até 15 anos e mais meninos que meninas. Uma história engraçada é a do zé de Biduca, que começou a estudar com 15 anos. O professor ensinava a soletrar en-xa-da, mas ele não conseguia dizer o que era. o professor dava uma dica: Zé, você trabalha com ela. E ele respondia: é foice. Soletrava "enxada" e lia "foice".

\section{Seus irmãos estudaram?}

Os quatro homens e as duas mulheres (Maria e Rosa) estudaram, as outras três não: as mais velhas não estudaram, só as mais novas.

\section{Mas por que a senhora não estudou?}

Uai, porque meu pai não deixava. Falavam que mulher não precisava estudar, porque só ia aprender a escrever carta pra namorado. Enedina, uma de minhas irmãs, risca o nome porque ela fazia bordado, porque era treinada em fazer flor, mas nunca foi na escola. Uns iam trabalhar e outros iam estudar. Meu pai falava que mulher não precisava estudar. As mais novas estudaram porque já eram outros tempos...

\section{Qual era o material escolar das crianças?}

Não tinha lousa. Os pais é que compravam todo o material, sem dar opinião. Sabe como a gente aprendia? O professor passava a lição e não tinha adulava ninguém. Ele falava uma vez, falava outra e outra. E, quando ninguém aprendia, ficava bravo, xingava, metia palmatória. Os meninos aprendiam a poder de palmatória. Enchiam a mão de bolo de palmatória. 


\section{Naquela época, o que era estudado?}

Os alunos aprendiam a fazer conta, a ler e escrever, a escrever com letra boa. E liam muito livro. Não lembro se aprenderam história, geografia, essas coisas.

\section{A senhora sentiu falta de não ter estudado?}

Muito. É a coisa que eu mais queria que meu pai me desse. Eu gosto muito de ir pra missa, conheço todas as letras, mas não sei juntar pra ler o livro da reza.

\section{$\mathbf{E}$ onde a senhora conheceu as letras?}

Meu marido me ensinou. Com 2 anos e 10 meses, ele me deixou assinando o nome. Todo dia ele me ensinava e, quando eu não aprendia, ele me dava "croque" na cabeça, nos dedos. Ele tinha vergonha de ser casado com uma moça analfabeta. Meu marido gostava muito de ler. Ele sabia muito, pois aprendeu em escola particular, na cidade, e não precisou trabalhar enquanto estudava. Se ele não tivesse morrido, eu saberia ler.

\section{Sua filha foi pra escola com qual idade?}

Sete anos. O estudo era na casa das pessoas, do mesmo jeito de quando eu era pequena, mas já não era na casa do meu pai.

\section{Depois sua filha se casou e teve os filhos dela. E a senhora foi acompanhando. Quando vocês vieram para são Paulo, a senhora também quis que seus netos estudassem.}

Pois é, todos estudaram, se mais não estudaram foi porque não quiseram. Até hoje, ainda tem gente estudando. O meu desejo é que todo mundo estude, se forme. Eu não aprendi, mas desejo que eles aprendam.

Mas, quando uma de suas netas deu aula pro Mobral, a senhora não foi aprender. Por quê?

Porque eu trabalhava fora a semana toda, até sábado e domingo. Não ficava um dia sequer em casa. Como é que eu ia aprender? 


\section{$\mathbf{E}$ hoje em dia...}

Numa época combinaram de todo mundo me ensinar e eu concordei. Mas aí a Beatriz, uma de minhas bisnetas, nasceu e eu tive que ajudar a cuidar dela.

\section{$\mathbf{E}$, hoje, a senhora ainda tem vontade de aprender?}

Fui à aula, durante dois dias, e fiquei doida: estava estudando do lado de uma louca que gritava e chorava. Eu me sentia mal com aquilo e não fui lá mais. Mas vou voltar na semana que vem.

\section{Na sua opinião, para que serve o estudo?}

Eu tenho muito sentimento de não saber ler porque, se eu soubesse ler, pegava um livro e via tudo o que tinha, pegava um jornal... ia distrair muito minha cabeça. Como eu não sei, com o que eu distraio?

\section{Mas a senhora nunca teve dificuldade pra pegar um ônibus, fazer compra no supermercado...}

Nunca tive. Nunca tomei prejuízo em conta. Pra isso, minha cabeça é boa. Eu ando sozinha, conheço todos os ônibus e não me atrapalho. É só marcar no papel, que eu soletro e compro qualquer coisa, eu não erro.

\section{De seus 8 netos, 5 mulheres estudaram na USP...}

Se elas tivessem trabalhado muito, não conseguiriam estudar na USP. Das filhas de minhas colegas, nenhuma estudou na USP, porque elas trabalhavam.

\section{A senhora quer deixar algum recado?}

O recado que eu tenho é pra você: muito obrigada por ter me procurado para ouvir tudo isso. 